\title{
Asia: A Lucrative Destination for Investment Banking
}

\author{
R. Vedapradha1, Ravi Hariharan', M. Ilankadhir ${ }^{2}$, D. Raja Jebasingh1 \\ ${ }^{1}$ Department of Commerce, St. Joseph's College of Commerce (Autonomous), Bangalore, India \\ ${ }^{2}$ School of Management Studies, Sathyabama Institute of Science and Technology, Chennai, India \\ Email: vedahariharan@gmail.com
}

How to cite this paper: Vedapradha, R., Hariharan, R., Ilankadhir, M. and Jebasingh, D.R. (2019) Asia: A Lucrative Destination for Investment Banking. Open Journal of Business and Management, 7, 1543-1552.

https://doi.org/10.4236/ojbm.2019.73106

Received: July 4, 2019

Accepted: July 27, 2019

Published: July 30, 2019

Copyright $\odot 2019$ by author(s) and Scientific Research Publishing Inc. This work is licensed under the Creative Commons Attribution International License (CC BY 4.0).

http://creativecommons.org/licenses/by/4.0/

\begin{abstract}
Purpose: The study aims to identify the reasons for the increase in the number of captive operations in urban Bangalore, which earlier was confined only to middle office and back end office but now venturing into front end office. Design/Methodology/Approach: The study includes 50 respondents, employees in the leading foreign-based investment banks operating in urban Bangalore, applying the snowball sampling method through a structured questionnaire. Business model, strategy, database, customized product, market research, operating cost, and employment are the variables. SPSS has been used to test the hypothesis through One-way ANOVA (Analysis of Variance). Findings: Employment, operating cost, and analytical skills are the key human resource factors impacting the performance. Business models, strategies, and customer database, are the significant factors of asset management. Attractive business avenues, eminent personnel, customer database are the formative factors of quality management. Job roles, portfolio seeding, segment business are the most highly influencing performance factors in offering excellent service to the clients by these banks as they are significant at 0.001 per cent level. Originality/Value: Investment banking reflects being one of the distinct segments which facilitates in capital formation, financial consultancies, advisory services, security trading, custodian services, investment management services, corporate actions, etc. This sector has transformed into a promising one in boosting the economy and financial services post-globalization. Most of the Asian nations are promising to be a silver line for the US and UK based Investment banks operating in Bangalore.
\end{abstract}

\section{Keywords}

Investment Banking, Quality Management, Operations, Foreign Investment 


\section{Introduction}

Asian markets have emerged as the strongest during the worldwide financial crunch during 2007 when compared to their US and European counterparts. However, it remains vulnerable to market volatility and economic uncertainty. Asia will emerge as both the largest and fastest-growing avenue for the investment banking increasing about 12 per cent annually with bonds complementing Foreign Exchange (FX) as attractive subsector driven by the globalization of large and mid-size Asian Corporations. Boutique investment banking is an emerging trend in the investment banking area as they are non-full servicing banking group that specializes in a specific activity of investment banking usually corporate finance, capital raising, mergers \& acquisitions, and organization restricting to cater to a specific category of clients [1]. There is an increasing trend of risk involved in the online banking performance in investment banks operated based in USA and UK, which are thriving towards attracting the stakeholders to invest in these large banks. Asian markets have different economic and managerial practices that protect the nations under its umbrella from being exposed to the financial crisis and also to continually shed efforts towards the performance of the banks. The study reveals that they create a holistic and dynamic economic environment can convert the weakness into strength [2]. Investment banking industry flourished in the USA and UK where the most financial activities originated, creating sophisticated centers in rendering the services to the clients across the globe. New York has been dominant in rendering the services to domicile clients while London was capturing the clients of global business. The Financial crisis in 2007 resulted in the downfall of the major financial activities in these two significant locations paving the way towards the emerging nations in Asia due to the lower cost of labor and handy qualified employees [3].

The research emphasizes on the prospective destination for venturing into front office operations across the Asian nations, especially with special reference to Indian economy due to its growing economy. India has always been a nation with the potential to benefit from low-cost operations. Therefore, the study enables focused on looking for opportunities concerning front office operations for which data collection is from the employees working in these banks in the vicinity of urban Bangalore. One-way ANOVA was performed to test the hypothesis concerning the significant contributions of human resource, asset management, service quality, and operational management in these banks, creating an edge over competitors. There were few glitches in collecting the data as the respondents were not willing to participate in the survey due to the sensitivity of the information revealed. They had to be assured of using the same only for academic research.

The structure of the article is structured as follows with the introduction to the concepts and key areas around the topic of research. The theoretical and conceptual framework is leading towards the area of study post identification of 
the gap. The key factors are indicating variables chosen for the study comprised of human resource, asset management, quality, and operations to test the hypothesis of the significant contributions towards the performance of the banks.

\section{Theoretical Background}

Asia has been a very lucrative continent for many business onlookers. The banking fundamentals play a pivotal role in ensuring the practices paving the way for the success of banks operating at a dangerous level concerning their liquidity levels. The author opined the study was to evaluate the factors influencing the failures of banks operating in Latin America and East Asia [4]. The investment banks offer one of the prominent services to their elite clients during Initial Public Offer (IPO). They promote the possibilities of striking a deal with the best of their capabilities; however, their results have a negative correlation between the valuation factor and the contemporary services [5]. The government of emerging nations promotes entry of foreign banks to venture into the nation to push the foreign exchange reserves and foreign direct investment to a greater level where the factor of the performance of the domestic banks gets affected. There is a negative correlation between the entry of foreign banks and the performance of domestic banks, along with the growth of a nation in terms of GDP [6]. Transformation in the technology and financial liberalization adopted by the developing nations has broken the barriers by the foreign banks gaining access to developing nations. These banks have improved their performance efficiencies when compared to the domestic banks based on parameters used to compare the performance of banks within the nation, different nations using a common variable, different nations using a nation-specific variable. The author has found out that the efficiency of foreign banks tends to outweigh domestic banks [7]. The paper contributes with significant outcomes confirming that among the selected sample of closely towards 8000 banks resulted that foreign banks have upper hand in generating higher profits when compared to their domestic counterparts among the various developing nations whereas their counterparts fail in the same during the vice versa situation [8]. Corporate governance has been one of the influencing factors for the financial crisis in Asia. The focus was on the controlling shareholders, and minority shareholders play a crucial role in bearing the agency cost in strengthening the reputation among the mechanism of the system across the corporate firms impacting with a lesser impact on the weak and poor priority institutions [9]. Asian countries have commendable fiscal balances with stringent banking regulations that prevent most of the financial crisis and encourage healthy survival of the banking industry which is also a reason for either slow development or expansion of the bond market in Asia [10]. Investment banks have the lowest and positive capital effect on profitability when compared to the commercial banks having the highest reverse capital at various risk levels. Banks operating at lower-income and middle-income nations have the highest reverse capital effect on risks. Levels of profitability are 
influenced by various variables when considered in the comparison of evaluation in deriving at profits [11]. Collaborations and alliances with firms have resulted in generating positive benefits in the US Investment banking industry while tested for inertia and evaluation of these banks towards the services rendered and their great performance in the context of underwriting syndicate formations [12].

\section{Conceptual Background}

The operational structure of investment banking classified into three parts, namely front office, middle office, and back-office setting the foundation to the various levels of operations performed in these banks. The front office activities have always been the prominent segment in these banks thriving to generate more profits which are confined to the consultancy services and creating business for specific fees. The middle office consists of the operational structure consists of risk management, evaluation of portfolio trades, analysis of risks, booking of trades, sending requests by sending swift messages to both custodian and brokerage firms, a quality check of records. The most important in the revenue generation is the back-office operations, which are the blend of technological division along with operational roles. The activities engaged in portfolio reconciliation, computing the value of the portfolio and compare the performance against a market index, client reporting, adjusting entries, expenses or incomes generated on the portfolios, etc. [13].

\section{Empirical Research}

\section{Research Model}

\section{Statement of the problem}

There are enormous avenues to the many foreign Investment banks to operate in most prominent Asian countries like India, China, Bangladesh, Pakistan, Sri Lanka, etc. The focus of the study is to explore the reasons attracting Foreign Investment Banks to venture into front end operations in Bangalore.

\section{Objectives}

$\checkmark$ Assess the key components in deriving the quality of service offered by human resource.

$\checkmark$ Assess the factors responsible for better asset management of the banks.

$\checkmark$ Understand the quality indicators in banks for effective performance.

$\checkmark$ Assess significant contributors are enhancing operations management. Sampling technique

The employees working in the Investment Banks currently operated in urban Bangalore selected for the study based on the snowball sampling technique comprising of 50 respondents.

\section{Data collection procedures}

The research has been focused only on the Investment banks operating in urban Bangalore. A Structured questionnaire has been designed based on the 
Linkert Scale to obtain the primary data from the respondents. The researcher visited the offices with prior permission and interacted with the respondents to collect the data.

\section{Variables}

Employment, operating cost, analytical skills, and meetings are human resource variables. Asset management variables are Revenue, business model, strategies, database, investment pattern. A lucrative business, resources, innovations, global solutions are quality management variables. Operations management variables comprises of job roles, challenges, portfolio seeding, expansion and segment.

Statistical tools \& tests used

Statistical Package for Social Science (SPSS) has been applied to analyze the One-Way Analysis of Variance (ANOVA) to test the hypothesis.

\section{Limitations}

The study was limited to just middle and back-office operations and couldn't explore the arenas of the front office. There were tedious legal process and documentation to complete before collecting the data from the respondents and instructed for confidentiality.

\section{Scope of future study}

There is scope to venture into more details of operational segments individually related to the front end, middle end, and back end.

\section{Hypothesis}

$\mathrm{H}_{0}^{1}$ : There is no significant difference between human resource and overall performance in services offered.

$\mathrm{H}_{0}^{2}$ : There is no significant difference between asset management and overall performance in services offered.

$\mathrm{H}_{0}^{3}$ : There is no significant difference between quality management and overall performance in services offered.

$\mathrm{H}_{0}^{4}$ : There is no significant difference between operations and overall performance in services offered.

\section{Results}

Table 1 reflects the components of the human resource comprising of employment opportunities, operating cost, analytical skills playing a vital role in the services offered by the Investment banks are significant at 0.001 per cent level. These banks increase employment opportunities in emerging country like India. Hence the null hypothesis (H0) is rejected and accept the alternative (H1) therefore there is a significant difference between employment, operating cost and analytical skills (human resource) and overall performance respective services offered by Foreign Investment Banks.

Table 2 reflects the components of the asset management comprising of revenue, business model, business strategies, customer database, and Investment pattern are significant at 0.001 per cent level. Hence the null hypothesis (H0) is 
rejected and accept the alternative (H1) therefore there is a significant difference between business model, strategies, Customer database (asset management) and overall performance respective services offered by Foreign Investment Banks.

Table 3 reflects the components of the quality management comprising of a lucrative business, key resources, innovations, and global solutions with a 1 per cent significance level. Hence the null hypothesis (H0) is rejected and accept the alternative $(\mathrm{H} 1)$ therefore there is a significant difference between lucrative business, essential resources, innovation, and integrated global solutions (quality management) and overall performance respective services offered by Foreign Investment Banks.

Table 4 reflects the components of the operations comprising of job roles, operational challenges, portfolio seeding, and Segment with 1 per cent significance level. Hence the null hypothesis ( $\mathrm{H} 0)$ is rejected and accept the alternative (H1) therefore there is a significant difference between Job roles, segment, challenges, and portfolio seeding (operations) and overall performance respective services offered by Foreign Investment Banks.

Table 1. Human resource components considered for rendering the quality service with better performance in these banks.

\begin{tabular}{ccccc}
\hline Factors & Particulars & Sum of Squares & F & Sig. \\
\hline \multirow{2}{*}{ Employment } & Between Groups & 92.562 & & \\
& Within Groups & 44.958 & 3.546 & $(0.001)^{* *}$ \\
& Total & 137.520 & & \\
Between Groups & 44.755 & & \\
Operating Cost & Within Groups & 21.825 & 3.532 & $(0.001)^{* *}$ \\
& Total & 66.580 & & \\
Analytical Skills & Wetween Groups & 87.563 & & \\
& Within Groups & 34.917 & 4.319 & $(0.000)^{* *}$ \\
& Total & 122.480 & & \\
Beetings & Witheen Groups & 18.962 & & \\
& Total & 18.958 & 1.723 & 0.089 \\
& Wroups & 37.920 & &
\end{tabular}

Source: Computed results based on primary data, ${ }^{* *} \operatorname{Sig} @ 0.001$.

Table 2. Components of asset management contributing towards to overall performance served by banks.

\begin{tabular}{ccccc}
\hline Factors & Particulars & Sum of Squares & F & Sig. \\
\hline \multirow{2}{*}{ Revenue } & Between Groups & 15.917 & & \\
& Within Groups & 18.083 & 1.516 & 0.150 \\
\multirow{2}{*}{ Business Model } & Total & 34.000 & & \\
\hline
\end{tabular}




\section{Continued}

\begin{tabular}{ccccc}
\hline & Within Groups & 10.117 & & \\
& Total & 28.880 & & \\
Between Groups & 17.488 & & \\
Strategies & Within Groups & 6.292 & 4.787 & $(0.000)^{* *}$ \\
& Total & 23.780 & & \\
Between Groups & 18.188 & & \\
Database & Within Groups & 4.292 & 7.299 & $(0.000)^{* *}$ \\
& Total & 22.480 & & \\
Between Groups & 7.247 & & \\
Investment Pattern & Within Groups & 7.333 & 1.702 & 0.094 \\
& Total & 14.580 & & \\
\hline
\end{tabular}

Source: Computed results based on primary data, ${ }^{*}$ Sig @ 0.001 level.

Table 3. Components of quality management contributing towards to overall performance served by banks.

\begin{tabular}{ccccc}
\hline Factors & Particulars & Sum of Squares & F & Sig. \\
\hline \multirow{2}{*}{ Lucrative Business } & Between Groups & 15.847 & & \\
& Within Groups & 11.033 & 2.474 & $(0.013)^{* *}$ \\
& Total & 26.880 & & \\
Key Resources & Between Groups & 16.875 & & \\
& Within Groups & 9.125 & 3.185 & $(0.002)^{* *}$ \\
& Total & 26.000 & & \\
Innovations & Between Groups & 13.042 & & $(0.002)^{* *}$ \\
& Within Groups & 6.958 & 3.228 & \\
& Total & 20.000 & & \\
Global Solutions & Between Groups & 81.513 & & $(0.000)^{* *}$ \\
& Within Groups & 26.667 & \multirow{2}{*}{5.264} & \\
\hline
\end{tabular}

Source: Computed results based on primary data, ${ }^{*}$ Sig @ 0.001 level.

Table 4. Components of operations contributing towards to overall performance served by banks.

\begin{tabular}{ccccc}
\hline Factors & & Sum of Squares & F & Sig. \\
\hline \multirow{3}{*}{ Job Roles } & Between Groups & 80.003 & & \\
& Within Groups & 32.417 & 4.250 & $(0.000)^{* *}$ \\
& Total & 112.420 & & \\
Challenges & Between Groups & 85.703 & & \\
& Within Groups & 29.917 & 4.934 & $(0.000)^{* *}$ \\
& Total & 115.620 & & \\
\hline
\end{tabular}




\section{Continued}

\begin{tabular}{ccccc}
\hline & Between Groups & 25.062 & & \\
Portfolio seeding & Within Groups & 6.958 & 6.203 & $(0.000)^{* *}$ \\
& Total & 32.020 & & \\
Between Groups & 7.512 & & \\
Expansion & Within Groups & 11.208 & 1.154 & 0.353 \\
& Total & 18.720 & & \\
Segment & Between Groups & 29.572 & & \\
& Within Groups & 12.208 & 4.172 & $(0.000)^{* *}$ \\
& Total & 41.780 & & \\
\hline
\end{tabular}

Source: Computed results based on primary data, **Sig @ 0.001 level.

\section{Findings}

Employment, operating cost, and analytical skills are the key factors influencing the foreign-based banks to venture into developing nations. The Bangalore offers highly talented and competent human resource at low operating cost than other Asian countries, and they also involve their corporate investors in the meetings with board members which is not significant during the decision making the process. Analytical skills are expected to address the issues concerned with the problem-solving ability and is the most influencing factor underlying the human resource management with $\mathrm{F}$ value (4.319) being highest. Business models, strategies, customer database, are the crucial factors of asset management influencing the performance of the banks. The front and middle office operations generate more revenue when compared to the back-end office in developed nations. Specific business models and strategies are adapted to create an edge over others. Customer Database is the most influencing factor underlying the customer database with F value (7.299) being highest. Investment pattern does not play a significant role in the process of asset management because Bangalore offices don't handle the decisions about portfolio management until recent times post 2018. Attractive business avenues, personnel resources, technological innovations, and offering solutions to the clients across the globe have been the trump card of these banks. Global solutions are the most influencing factor underlying the global solutions with F value (5.264) being highest as the operations are decentralized by the head office to obtain benefit from the time gap between India and Western nations. Innovative and Integrated global solutions facilitate robust and effective sales and trading with effective business decisions. The quality of service also plays an important role where skilled employees have proved their ability in the middle office and back end operations, which also has paved the way for venturing into front office operations. Job roles, operating challenges, portfolio seeding, and segment focus based services contribute to the success of operative efficiency among these banks. Portfolio seeding is the most influencing factor underlying the operations with $\mathrm{F}$ value (6.203) being highest. 
Portfolio management is a crucial aspect of operations management that primarily focus on the decisions towards selecting the apt portfolio, the timing of investment, classifying the asset class, managing the funds on behalf of the clients. The roles of the employees are clearly defined. Expansion of the business is not significant towards the operations management as these banks do not have front end office in Bangalore.

\section{Conclusion}

South Asian countries have been relatively performing well when compared to their western counterparts in the area of investment banking due to a very reserved methodology of banking operations concerning lending, credit policies, etc. Analytical skills are the most influencing component of human resource to deliver quality service to the clients. Customer database is the prominent influencing factor as this promotes effective asset management. Innovative and integrated global solutions facilitate robust and effective sales and trading with effective business decisions that retain the quality of service. Portfolio seeding is the most influencing factor underlying the operations. Since there is a huge success of the middle office and back office operated by foreign investment banks in Bangalore, they have ventured into the front-end office segment to generate more revenue and take advantage of timings.

\section{Conflicts of Interest}

The authors declare no conflicts of interest regarding the publication of this paper.

\section{References}

[1] Cain, A. (2012) Capitalising on the Asian Opportunity. Finance: The Magazine for Finsia Members, 126, 14.

[2] Li, P. and Chang, T.L. (2001) The Asian Paradox of Miracle and Debacle: An Exploratory Study. Asian Financial Crisis Financial, Structural and International Dimensions. Emerald Group Publishing Limited, West Yorkshire, 411-435.

[3] Wójcik, D., Pažitka, V., Knight, E. and O’Neill, P. (2018) Investment Banking Centres Since the Global Financial Crisis: New Typology, Ranking and Trends. Environment and Planning A: Economy and Space, 51, 687-704.

[4] Arena, M. (2008). Bank Failures and Bank Fundamentals: A Comparative Analysis of Latin America and East Asia during the Nineties Using Bank-Level Data. Journal of Banking \& Finance, 32, 299-310. https://doi.org/10.1016/j.jbankfin.2007.03.011

[5] Benveniste, L.M., Ljungqvist, A., Wilhelm Jr., W.J. and Yu, X. (2003) Evidence of Information Spillovers in the Production of Investment Banking Services. The Journal of Finance, 58, 577-608. https://doi.org/10.1111/1540-6261.00538

[6] Bayraktar, N. and Wang, Y. (2004) Foreign Bank Entry, Performance of Domestic Banks, and Sequence of Financial Liberalization. World Bank Policy Research Working Paper, No. 3416.

[7] Berger, A.N. (2007) International Comparisons of Banking Efficiency. Financial Markets, Institutions \& Instruments, 16, 119-144. 
https://doi.org/10.1111/j.1468-0416.2007.00121.x

[8] Claessens, S., Demirgüç-Kunt, A. and Huizinga, H. (2001) How Does Foreign Entry Affect Domestic Banking Markets? Journal of Banking \& Finance, 25, 891-911. https://doi.org/10.1016/S0378-4266(00)00102-3

[9] Claessens, S. and Fan, J.P. (2002) Corporate Governance in Asia: A Survey. International Review of Finance, 3, 71-103. https://doi.org/10.1111/1468-2443.00034

[10] Eichengreen, B. and Luengnaruemitchai, P. (2004) Why Doesn't Asia Have Bigger Bond Markets? National Bureau of Economic Research, No. w10576. https://doi.org/10.3386/w10576

[11] Lee, C.C. and Hsieh, M.F. (2013) The Impact of Bank Capital on Profitability and Risk in Asian Banking. Journal of International Money and Finance, 32, 251-281. https://doi.org/10.1016/j.jimonfin.2012.04.013

[12] Li, S.X. and Rowley, T.J. (2002) Inertia and Evaluation Mechanisms in Interorganizational Partner Selection: Syndicate Formation among US Investment Banks. Academy of Management Journal, 45, 1104-1119.

[13] Vedapradha, R., Ravi, H. and Jebasingh, R. (2016) Investment Banking-A Panacea for Economic Development in Banking Sector. International Journal of Business Quantitative Economics and Applied Management Research, 3, 44-50. 